\title{
Safety and efficacy of catheter ablation for atrial fibrillation in abdominal solid organ (renal and hepatic) transplant recipients: a single-center pilot experience
}

\author{
Xin $\mathrm{Su}^{1}$, Xin Zhao ${ }^{2}$, Deyong Long ${ }^{3}$, Caihua Sang ${ }^{2}$, Rong-Hui Yu ${ }^{4}$, Ribo Tang ${ }^{3}$, Rong Bai ${ }^{2}$, \\ Nian Liu ${ }^{5}$, Chen-Xi Jiang ${ }^{4}$, Li Song-Nan ${ }^{6}$, Xue-Yuan Guo ${ }^{4}$, Wei Wang ${ }^{2}$, Rong Hu${ }^{7}$, Xin \\ $\mathrm{Du}^{1}$, Jian zeng Dong ${ }^{8}$, and Chang Sheng $\mathrm{Ma}^{2}$ \\ ${ }^{1}$ Capital Medical University Affiliated Anzhen Hospital \\ ${ }^{2}$ Beijing An Zhen Hospital \\ ${ }^{3}$ Capital Medical University \\ ${ }^{4}$ Beijing An Zhen Hospital, Capital Medical University \\ ${ }^{5}$ Capital University of Medical Sciences \\ ${ }^{6}$ Beijing Anzhen Hospital,Capital Medical University \\ 7 anzhen \\ ${ }^{8}$ Beijing Anzhen Hospital Capital Medical University
}

June 23, 2020

\begin{abstract}
Background: Atrial fibrillation (AF) is common in abdominal solid organ transplant recipients and a cause of morbidity and mortality in this population. However, the outcomes of catheter ablation (CA) in transplant recipients with AF remain unclear. This study aimed to elucidate the outcomes of CA in renal and hepatic transplant recipients. Methods and Results: Between 2015 and 2019, 14 transplant recipients (9 with kidney transplantation and 5 with liver transplantation) were enrolled from among 10,741 AF patients and underwent CA at Anzhen Hospital. Another 56 patients matched by age, sex and AF type were selected as the control group (4 controls for each transplant recipient). During a mean follow-up of $30.0 \pm 13.3$ months after the initial procedure, $10(71.4 \%)$ of the transplant patients, compared to $41(73.2 \%)$ of the control patients, remained free from $\mathrm{AF}$ recurrence $(\mathrm{P}=1.000)$. A repeated procedure was performed in 1 transplant patient and in 6 control subjects. Consequently, $11(78.6 \%)$ of the transplant patients, compared to $46(82.1 \%)$ of controls, were in sinus rhythm after the repeated ablation $(\mathrm{P}=0.715)$. Notably, Kaplan-Meier analysis did not demonstrate any significant differences in the atrial arrhythmia-free rate after the initial and repeated procedure between the two groups. Vascular complications were identified in 1 transplant patient and 2 control subjects, while no life-threatening complications were observed in either group. There was no transient allograft dysfunction in transplant recipients after CA. Conclusion: CA is safe and effective in abdominal solid transplant recipients, and may be an optimal therapeutic strategy for this group.
\end{abstract}

\section{Introduction}

Atrial fibrillation (AF) is one of the most common cardiac arrhythmias, affecting almost 30 million people worldwide and expected to reach 50 million people worldwide in $2050^{1,2}$. Patients with $\mathrm{AF}$ have a higher risk of reduced survival and adverse cardiovascular and cerebrovascular events ${ }^{3,4}$. These epidemiological estimates could be extended to organ transplant recipients. Studies show that end-stage renal disease and end-stage hepatic disease patients who receive organ grafting have an AF prevalence of $7.0 \%$ and $5.6 \%$, respectively, and these values are higher than that of the general population $(1 \%-2 \%)^{5-8}$. In addition, studies 
have demonstrated pooled incidences of post-kidney transplant AF and post-liver transplant AF of $4.9 \%$ and $8.5 \%$, respectively ${ }^{7,8}$.

Because of ongoing improvements in surgery and medicine, the number of organ transplant patients is steadily increasing 9,10 . These transplant recipients usually carry multiple comorbidities and require individualized treatment. Previous studies have shown that AF is associated with inferior survival in abdominal solid organ transplant recipients ${ }^{11-13}$. In addition, the treatment of $\mathrm{AF}$ in solid organ transplant recipients by using antiarrhythmic drugs (AADs) is often difficult ${ }^{14-17}$, and non-vitamin $\mathrm{K}$ antagonist oral anticoagulants (NOACs) may interact with immunosuppressive agents ${ }^{18,19}$. Therefore, a more reliable treatment for AF in solid organ transplant recipients is needed.

In recent years, catheter ablation $(\mathrm{CA})$ for $\mathrm{AF}$ has proven to be a safe and effective treatment strategy for patients with symptomatic $\mathrm{AF}^{20}$. However, the feasibility and outcomes of $\mathrm{CA}$ in abdominal solid organ transplant recipients with AF remain unclear. In the present study, we aimed to elucidate the feasibility, efficacy and safety of CA in renal and hepatic transplant recipients.

\section{Methods}

\section{Study population}

From October 2015 to December 2019, 10,741 cases of CA for AF were screened from the database of AF center of Anzhen Hospital. Fourteen patients with kidney or liver transplantation (9 patients with kidney transplantation and 5 patients with liver transplantation) who underwent the first CA for AF were enrolled in the present study. Meanwhile, another $56 \mathrm{AF}$ patients without kidney or liver transplantation matched by age, sex and AF type were selected as the controls (4 controls for each renal or hepatic transplant recipient). The exclusion criteria included valvular AF, previous CA for AF and a follow-up of less than six months.

\section{Data collection}

From each patient, besides demographic data [body mass index (BMI), age, gender], we collected the AF type, AF duration, medical history [hypertension, heart failure (HF), prior stroke/transient ischemic attack (TIA), coronary heart disease (CAD) and diabetes mellitus (DM)], hematological indices [hemoglobin (Hb), platelet (PLT) count], serum biochemical parameters [aspartate aminotransferase (AST), alanine aminotransferase (ALT), direct bilirubin (DBIL), total bilirubin (TBIL), creatinine], echocardiographic parameters [left ventricular end diastolic diameter (LVEDD), left atrium diameter (LAD), left ventricular ejection fraction (LVEF)], $\mathrm{CHA}_{2} \mathrm{DS}_{2}$-VASc score, HAS-BLED score, EHRA stratification and medical therapy (drugs for rhythm control, rate control and anticoagulation). We estimated the glomerular filtration rate (eGFR) according to the Cockcroft-Gault equation.

For renal and hepatic transplant recipients, we also reviewed the history of transplantation, the time from transplantation to ablation and the combination of immunosuppressive drugs.

\section{Immunosuppression}

All organ recipients were on immunosuppression, and the immunosuppressive therapy was continued as previously prescribed. Immunosuppressive drugs included mammalian target of rapamycin inhibitors (sirolimus), calcineurin inhibitors (cyclosporine or tacrolimus), antimetabolite (azathioprine or mycophenolate mofetil) and corticosteroids (prednisone or methyl prednisolone). Drug monitoring was carried out during the perioperative period to reach the required dose. No patient in the matching group was on immunosuppression for any reason. The function of transplanted organ was closely monitored during the perioperative period.

\section{Catheter ablation procedure}

In the present study,patients underwent left atrial and pulmonary venous computed tomography angiography or transesophageal echocardiography prior to CA to rule out thrombosis. The strategy of CA for AF in our center has been described before ${ }^{21}$. In brief, after atrial septal puncture, a $3.5 \mathrm{~mm}$ tip ablation catheter was used to reconstruct the left atrial geometry under the guidance of the CARTO system. In patients with 
paroxysmal AF, pulmonary vein isolation (PVI) was performed with the endpoint of electrical isolation. In addition, patients with recordings of typical atrial flutter underwent tricuspid isthmus ablation. In patients with persistent $\mathrm{AF}$, linear ablation (mitral isthmus line, left atrial roof line and cavotricuspid isthmus line) was performed in addition to PVI, with the endpoint of bidirectional block across each of the 3 ablation lines as described previously. If the sinus rhythm (SR) was not reached after the ablation procedure, cardioversion was performed. For the repeated procedure, in brief, the pulmonary veins (PVs) were checked to assess the PV reconduction, and PVI was achieved by the gap ablation. Moreover, if necessary, additional ablation was performed (such as complex fractionated atrial electrograms, superior vena cava) at the discretion of the operator.

Continuous infusion of heparin during the ablation was used to maintain the activated clotting time (ACT) of 300-400 seconds. We monitored every 30 minutes throughout the ablation procedure to maintain the target ACT.

\section{Medical therapy and anticoagulation management}

All AADs were stopped for at least 5 half-lives before CA (amiodarone was discontinued for at least 1 month). After CA, all patients received NOACs or warfarin for at least 2 months. A type I or III antiarrhythmic drug would be prescribed for eligible patients after ablation for 3 months. After the first 3 months of the blanking period, the choice of continuing anticoagulant was left to the physician's discretion. For patients with any atrial tachyarrhythmia episode, anticoagulant therapy was recommended if the $\mathrm{CHA}_{2} \mathrm{DS}_{2}$-VASc score was [?] 2.

\section{Follow-up}

Each enrolled patient was followed up at 3,6 and then every 6 months subsequently by trained staff, either through a telephone interview or at an outpatient clinic. During each follow-up, information related to clinical results and medical treatment was collected. In addition, 24-hour Holter monitoring was performed, and 12-lead electrocardiograms were recorded at every visit. Additional electrocardiograms were performed if arrhythmic symptoms occurred. No atrial tachyarrhythmia lasting at least 30 seconds beyond the 3-month blanking period was defined as successful ablation.

\section{Statistical analysis}

The data are presented as frequencies and percentages for qualitative variables and means \pm standard deviations for quantitative variables. To compare the two groups, Mann-Whitney U tests were used for continuous variables, and $\chi^{2}$ tests or Fisher exact tests were used for categorical variables. Kaplan-Meier analysis was performed to assess the time required for recurrence of AF. The AF-free survival was compared by log-rank test. Statistical analyses were performed using SPSS 23.0 software (Chicago, IL, USA). For all analyses, a P-value of $<0.05$ was considered statistically significant.

\section{Results}

Fourteen patients with kidney or liver transplantation (9 patients with kidney transplantation and 5 patients with liver transplantation) underwent CA between 2015 and 2019 in our center. Another 56 AF patients (ratio of 1:4) who were matched by age, sex and AF type and had no history of solid organ transplantation were selected as controls.

\section{Baseline characteristics}

The clinical characteristics of the transplant patients and controls are presented in Table 1. All of the variables studied with respect to demographics (age, gender and BMI), AF type, AF duration, medical history (hypertension, HF, prior stroke/TIA, DM and CAD), echocardiographic parameters (LA, LVEDD and LVEF), EHRA stratification and medical therapy were comparable between the two groups. Transplant patients had relatively higher $\mathrm{CHA}_{2} \mathrm{DS}_{2}$-VASc and HAS-BLED scores than the controls. The mean eGFR was $80.3 \pm 13.9 \mathrm{ml} / \mathrm{min} / 1.73 \mathrm{~m}^{2}$ in the transplant group and $91.9 \pm 12.6 \mathrm{ml} / \mathrm{min} / 1.73 \mathrm{~m}^{2}$ in the control group $(\mathrm{P}=0.007)$. The preoperative creatinine concentration was higher in the transplant group than in the control 
group ( $88.4 \pm 22.8$ vs. $74.6 \pm 14.7, \mathrm{P}=0.017$ ), whereas the levels of ALT, AST, TBIL, DBIL, Hb and PLT were comparable between the two groups.

The detailed clinical features of the transplant recipients are shown in Table 2. The mean age at the time of ablation was 59.0 \pm 5.5 years for all transplant patients, and the median time from transplantation to CA was $10.3 \pm 5.5$ years. The mean duration of the AF episode before CA was $47.6 \pm 45.1$ months. Males made up the majority of the transplant group $(\mathrm{n}=11 ; 78.6 \%)$. Seven patients $(77.8 \%)$ in the renal transplant recipients and four patients $(80.0 \%)$ in the hepatic transplant recipients were male. Most transplant patients had a history of hypertension $(\mathrm{n}=11 ; 78.6 \%)$. All patients in the transplant group were on immunosuppressive therapy.

\section{Procedural characteristics and complications}

A comparison of procedural characteristics between the two groups is shown in Table 3. All ablation procedures were successfully completed. There was no difference in the mean procedure time or mean fluoroscopic time between the two groups. Moreover, the strategies for CA did not differ between the two groups.

Among the periprocedural complications listed in Table 3, there was no significant difference in the rate of procedure-related complications between the two groups. In the transplant group, one recipient suffered a minor groin hematoma. In the control group, one patient suffered a minor groin hematoma, and one patient developed a small pseudoaneurysm. Importantly, there was no procedure-related thromboembolism or major bleeding in the two groups.

\section{Renal and hepatic functions}

The kidney and liver functions before operation are shown in Table 2, and the changes after the ablation are outlined in Figure 1. There was no significant transient allograft dysfunction in the renal transplant recipients after $\mathrm{CA}$, as demonstrated by the serum creatinine ( $89.4 \pm 27.7$ vs. $91.3 \pm 29.6, \mathrm{P}=0.666)$ and eGFR ( $80.4 \pm 15.6$ vs. $78.4 \pm 16.6, \mathrm{P}=0.489)$ trends. Similarly, there was no significant transient liver dysfunction in hepatic transplant recipients after $\mathrm{CA}$, as demonstrated by the AST $(24.8 \pm 5.5$ vs. $33.6 \pm 8.6, \mathrm{P}=0.095)$ and ALT (24.6 \pm 10.5 vs. $31.6 \pm 12.9, \mathrm{P}=0.310)$ trends.

\section{Outcomes}

In the transplant group, the initial procedure success rate was $71.4 \%(\mathrm{n}=10)$ after a mean follow-up of $30.1 \pm 13.7$ months. Meanwhile, the initial procedure success rate was $73.2 \%(\mathrm{n}=41)$ after a mean follow-up of $29.9 \pm 13.4$ months in the control group. The procedure success rate was comparable between the two groups $(\mathrm{P}=1.000)$. There was no difference between the two groups in terms of whether the AF was paroxysmal ( $72.7 \%$ vs. $72.7 \%, \mathrm{P}=1.000$ ) or persistent $(66.7 \%$ vs. $75.0 \%, \mathrm{P}=1.000)$. All patients with a successful procedure were not taking AADs. The prognosis after initial ablation (as estimated by Kaplan-Meier analysis) is shown in Figure 2A-B. The recurrence of AF was consistent between the transplant recipients and the controls (logrank $\mathrm{P}=0.935)$, and $\mathrm{AF}$ recurrence-free survival was comparable among renal transplant recipients, hepatic transplant recipients and controls.

One patient $(7.1 \%)$ in the transplant group and six patients $(10.7 \%)$ in the control group underwent repeat ablation for recurrent AF. Of these, reconnected PVs were noted in six patients. Among the seven patients undergoing a repeated procedure, one patient in the control group suffered recurrent AF. Finally, during a mean follow-up period of $27.8 \pm 14.2$ months after repeated ablation, $11(78.6 \%)$ of the transplant patients, compared to $46(82.1 \%)$ of the controls, remained in $\mathrm{SR}$ without any AAD ( $\mathrm{P}=0.715)$. The prognosis after repeated ablation estimated by Kaplan-Meier analysis is shown in Figure 2C-D. The recurrence of AF was consistent between the two groups (log-rank $\mathrm{P}=0.740$ ), and $\mathrm{AF}$ recurrence-free survival was comparable among renal transplant recipients, hepatic transplant recipients and controls.

During follow-up, there were no occurrences of cardiac arrest, thromboembolism, major bleeding or all-cause death among the transplant recipients.

\section{Discussion}


To the best of our knowledge, this is the first study addressing the outcomes of CA in renal and hepatic transplant patients with AF. We found no significant differences between the transplant group and control group with respect to atrial arrhythmia event-free rate after the initial and repeated procedures. Furthermore, there was no significant difference in the incidence of procedure-related complications between the two groups, and there was no transient allograft dysfunction in the transplant recipients after CA.

$\mathrm{AF}$ is common in abdominal solid-organ transplant recipients ${ }^{11}$. Previous studies have demonstrated that the prevalence of preexisting AF in renal and hepatic transplant recipients is $7.0 \%$ and $5.6 \%$, respectively, and that the incidence of AF after kidney and liver transplantation is $4.9 \%$ and $8.5 \%$, respectively ${ }^{7,8}$. The high prevalence of AF may mean that patients receiving kidney or liver transplants appear to be at higher risk ${ }^{22-24}$. Besides, long-term application of immunosuppressants after transplantation might lead to or accelerate cardiovascular diseases. ${ }^{25,26}$. Patients with AF carry a higher risk of mortality and adverse cardiovascular events ${ }^{3}$. Previous studies have shown that AF is associated with inferior survival in abdominal solid organ transplant recipients, and the impact of AF on morbidity and mortality in these recipients is striking ${ }^{11-13}$.

The beneficial effect of CA on maintaining SR and improving quality of life has already been confirmed ${ }^{27}, 28$. The CASTLE-AF study noted that compared with medical therapy, CA for treating AF in patients with $\mathrm{HF}$ was associated with a $47 \%$ lower rate of mortality ${ }^{29}$. The present study showed that the SR maintenance rate in the abdominal solid-organ transplant recipients after the initial (71.4\%) and repeated (78.6\%) CA sessions did not differ from that in the matched group. In addition, there was no significant difference in the incidence of procedure-related complications between the two groups. These findings indicated that the ablation procedure might be an appropriate choice for the treatment of AF in renal and hepatic transplant recipients. In this study, none of the recipients died during the follow-up period. Considering the higher cardiovascular risk factors in solid organ transplant recipients with $\mathrm{AF}$, they might benefit from $\mathrm{CA}$ in the long term. Next, studies should focus on whether CA could improve the long-term survival of abdominal transplant recipients with $\mathrm{AF}$.

$\mathrm{AF}$ is associated with a higher risk of stroke, and AF-related stroke leads to more fatalities and is more disabling than non-AF stroke ${ }^{30}$. Anticoagulants are an effective therapy to prevent AF patients from suffering stroke $^{31}$. However, in renal and hepatic transplant recipients with AF, who are populations at high cardiovascular risk, evidence regarding the efficacy and safety of anticoagulation for AF is lacking. A retrospective study highlighted that only $24 \%$ of kidney transplant recipients with newly diagnosed AF received warfarin, which was less than the general population $(51 \%)$. The retrospective study also found that warfarin was associated with a small nonsignificant reduction in the composite outcome of death, stroke or gastrointestinal bleeding in renal transplant recipients with $\mathrm{AF}$ [hazard ratio=0.92, 95\% confidence interval 0.83-1.02 ${ }^{32}$.

In the general population with nonvalvular atrial fibrillation, NOACs are increasingly used, replacing vitamin $\mathrm{K}$ antagonist anticoagulants and demonstrating efficacy and safety in thromboembolism prevention ${ }^{33}$. To date, data regarding the clinical use of NOACs in renal and hepatic transplant recipients are limited ${ }^{34,35}$. NOACs may interact with immunosuppressive therapy ${ }^{18,19}$. All NOACs are substrates of the multidrug transporter P-glycoprotein (P-gp), with apixaban and rivaroxaban also being substrates of CYP450 3A4. Calcineurin inhibitors (CNIs) are known substrates of CYP450 3A4 and P-gp, and also inhibitors of P-gp. In the present study, all the allograft recipients were maintained by CNIs. Concomitant prescription with NOACs might increase NOAC plasma levels and lead to an increased risk of bleeding. In this particular condition, pharmacokinetic/pharmacodynamic drug monitoring might be helpful to limit the risks of drugdrug interactions. In our study, there were no thrombotic or bleeding events in renal and hepatic transplant recipients using NOACs during the perioperative and follow-up periods. Abdominal solid organ recipients are vulnerable groups suffered variations in kidney or liver functions and are at higher risk of thrombotic and bleeding complications, with possible interactions with immunosuppressive agents. Given these issues, achieving long-term SR maintenance by CA in renal and hepatic transplant recipients may be a good choice to minimize the need for oral anticoagulants.

The treatment options available to achieve effective rhythm control in renal and hepatic transplant recipients 
are limited. The coexistence of comorbidities and risk of drug interactions caused by polypharmacological therapy restrain the use of AADs. Amiodarone-tacrolimus interactions leading to QT prolongation and fatal arrhythmias in transplant recipients have been reported ${ }^{16,17}$. In addition, dronedarone might increase tacrolimus levels, promote tacrolimus toxicity and potentially extend the QT interval in the electrocardiogram ${ }^{14,}{ }^{15}$. Accordingly, AADs are rarely prescribed for $>3$ months due to the increased risk of drug interactions in solid organ transplant recipients. In the present study, all transplant recipients with AF discontinued AADs after successful ablation. With these premises, achieving long-term SR maintenance through CA in renal and hepatic transplant recipients appears crucial to minimize the need for AADs.

\section{Study Limitations}

This investigation has several limitations. First, it was a retrospective single-center study with a small number of subjects, and therefore, the power is limited. Second, selection bias is a potential problem. The renal and hepatic transplant recipients selected for CA might have been healthier and more symptomatic than those who were not selected, and they might also have been more likely to be cared for by arrhythmia specialists. Thus, our patient population may not be representative of the broader population of patients with kidney and liver transplantation. Finally, the rate of absence of AF after CA might be overestimated because of possibility of missing an asymptomatic recurrence of AF. Conclusions

In conclusion, $\mathrm{CA}$ for $\mathrm{AF}$ is safe and effective in renal and hepatic transplant recipients and may be a suitable treatment for AF in transplant recipients. Larger studies are needed to confirm these results and to investigate the long-term effects of $\mathrm{CA}$ in renal and hepatic transplant recipients.

\section{References}

1. Schnabel RB, Yin X, Gona P, Larson MG, Beiser A, Mcmanus DD, Newtoncheh C, Lubitz SA, Magnani JW, Ellinor PT, Seshadri S, Wolf PA, Vasan RS, Benjamin EJ, Levy D: 50 year trends in atrial fibrillation prevalence, incidence, risk factors, and mortality in the Framingham Heart Study: a cohort study. Lancet 2015;386:154-162.

2. Zoniberisso M, Lercari F, Carazza T, Domenicucci S: Epidemiology of Atrial Fibrillation: European Perspective. Clin Epidemio 2014;6:213-220.

3. Odutayo A, Wong CX, Hsiao AJ, Hopewell S, Altman DG, Emdin CA: Atrial fibrillation and risks of cardiovascular disease, renal disease, and death: systematic review and meta-analysis. Clin Epidemio 2016;354:i4482

4. Chugh SS, Havmoeller R, Narayanan K, Singh D, Rienstra M, Benjamin EJ, Gillum RF, Kim YH, Mcanulty JH, Zheng ZJ, Forouzanfar MH, Naghavi M, Mensah GA, Ezzati M, Murray CJ: Worldwide Epidemiology of Atrial Fibrillation A Global Burden of Disease 2010 Study. Circulation 2014;129:837-847.

5. Go AS, Hylek EM, Phillips KA, Chang Y, Henault LE, Selby JV, Singer DE: Prevalence of Diagnosed Atrial Fibrillation in Adults: National Implications for Rhythm Management and Stroke Prevention: the AnTicoagulation and Risk Factors In Atrial Fibrillation (ATRIA) Study. JAMA 2001;285:2370-2375.

6. Heeringa J, van der Kuip DA, Hofman A, Kors JA, van Herpen G, Stricker BHC, Stijnen T, Lip GY, Witteman JC: Prevalence, incidence and lifetime risk of atrial fibrillation: the Rotterdam study. Eur Heart J 2006;27:949-953.

7. Thongprayoon C, Chokesuwattanaskul R, Bathini T, Khoury NJ, Sharma K, Ungprasert P, Prasitlumkum N, Aeddula NR, Watthanasuntorn K, Salim SA, Kaewput W, Koller FL, Cheungpasitporn W: Epidemiology and Prognostic Importance of Atrial Fibrillation in Kidney Transplant Recipients: A Meta-Analysis. J Clin Med 2018;7:370.

8. Chokesuwattanaskul R, Thongprayoon C, Bathini T, Ungprasert P, Sharma K, Wijarnpreecha K, Pachariyanon $\mathrm{P}$, Cheungpasitporn $\mathrm{W}$ : Liver transplantation and atrial fibrillation: A meta-analysis. World Journal 
of Hepatology 2018;10:761-771.

9. Brennan DC: Long-term trends in allograft survival. Adv Chronic Kidney D 2006;13:11-17.

10. Sanchez CA, Higueras MM, Fernandez-Felechosa JM, Gutierrez JM, Moreno PM, Fernandez NG, Royo FL, Goenaga PE: Short-term outcomes of 100 consecutive kidney transplantations in a 3-year period: a single-center experience. Transpl P 2016;48:2906-2909.

11. Molinari M, Sood P, Samra PB, Tevar AD, Ganoza A, Jonassaint N, Puttarajappa C: Atrial fibrillation in renal or liver transplant recipients: A systematic review and meta-analysis. Transplantation Reviews 2019;33:29-38.

12. Bargehr J, Trejogutierrez JF, Patel TC, Rosser BG, Arandamichel J, Yataco M, Taner CB: Preexisting atrial fibrillation and cardiac complications after liver transplantation. Liver Transplant 2015;21:314-320.

13. Lenihan CR, Montezrath ME, Scandling JD, Turakhia MP, Winkelmayer WC: Outcomes After Kidney Transplantation of Patients Previously Diagnosed With Atrial Fibrillation. Am J Transplant 2013;13:15661575 .

14. Marincasino M, Perezsaez MJ, Crespo M, Echeverria D, Mir M, Pascual J: Significant tacrolimus and dronedarone interaction in a kidney transplant recipient. Transplantation 2014;98:33-34

15. Tichy EM, Medwid AJ, Mills EA, Formica RN, Kulkarni S: Significant Sirolimus and Dronedarone Interaction in a Kidney Transplant Recipient. Ann Pharmacother 2010;44:1338-1341.

16. Burger CI, Clase CM, Gangji AS: Case report: drug interaction between tacrolimus and amiodarone with QT prolongation. Transplantation 2010;89:1166-1167.

17. Kisters K, Cziborra M, Funke C, Brylak S, Hausberg M: Amiodarone-tacrolimus interaction in kidney transplantation. Clin Nephrol 2008;70:563.

18. Leon J, Sabbah L, Aubert O, Anglicheau D, Delavenne X, Zuber J, Amrouche L, Scemla A, Giura G, Divard G, Legendre C, Sberro-Soussan R: Efficacy and safety of direct oral anticoagulants in kidney transplantation: a single-center pilot experience. Transplantation 2020.

19. Salerno DM, Tsapepas D, Papachristos A, Chang J, Martin ST, Hardy MA, Mckeen J: Direct oral anticoagulant considerations in solid organ transplantation: A review. Clin Transplant 2017;31: 10.1111/ctr.12873

20. Calkins H, Hindricks G, Cappato R, et al: 2017 HRS/EHRA/ECAS/APHRS/SOLAECE expert consensus statement on catheter and surgical ablation of atrial fibrillation. Heart Rhythm 2017;14:275-444.

21. Dong JZ, Sang CH, Yu RH, Long DY, Tang RB, Jiang CX, Ning M, Liu N, Liu XP, Du X, Tse HF, Ma CS: Prospective randomized comparison between a fixed '2C3L' approach vs. stepwise approach for catheter ablation of persistent atrial fibrillation. Europace 2015;17:1798-1806.

22. De Mattos AM, Prather JC, Olyaei AJ, Shibagaki Y, Keith D, Mori M, Norman DJ, Becker T: Cardiovascular events following renal transplantation: Role of traditional and transplant-specific risk factors. Kidney Int 2006;70:757-764.

23. Johnston SD, Morris JK, Cramb R, Gunson BK, Neuberger J: Cardiovascular morbidity and mortality after orthotopic liver transplantation. Transplantation 2002;73:901-906.

24. Fussner LA, Heimbach JK, Fan C, Dierkhising RA, Coss E, Leise MD, Watt KD: Cardiovascular disease after liver transplantation: When, What, and Who Is at Risk. Liver Transplant 2015;21:889-896.

25. Rabkin JM, Corless CL, Rosen HR, Olyaei AJ: Immunosuppression impact on long-term cardiovascular complications after liver transplantation. Am J Surg 2002;183:595-599.

26. Gill JS: Cardiovascular Disease in Transplant Recipients: Current and Future Treatment Strategies. Clin J Am Soc Nephrol 2008;3:S29-37 
27. Mark DB, Anstrom KJ, Sheng S, Piccini JP, Baloch K, Monahan KH, Daniels MR, Bahnson TD, Poole JE, Rosenberg Y, Lee KL, Packer DL; CABANA Investigators: Effect of Catheter Ablation vs Medical Therapy on Quality of Life Among Patients With Atrial Fibrillation: The CABANA Randomized Clinical Trial. JAMA 2019;321:1275-1285.

28. Blomstromlundqvist C, Gizurarson S, Schwieler J, Jensen SM, Bergfeldt L, Kenneback G, Rubulis A, Malmborg H, Raatikainen P, Lonnerholm S, Hoglund N, Mortsell D: Effect of Catheter Ablation vs Antiarrhythmic Medication on Quality of Life in Patients With Atrial Fibrillation: The CAPTAF Randomized Clinical Trial. JAMA 2019;321:1059-1068.

29. Marrouche NF, Brachmann J, Andresen D, Siebels J, Boersma LVA, Jordaens L, Merkely B, Pokushalov E, Sanders P, Proff J, Schunkert H, Christ H, Vogt J, Bansch D; CASTLE-AF Investigators: Catheter Ablation for Atrial Fibrillation with Heart Failure. New Engl J Med 2018;378:417-427.

30. Lin H, Wolf PA, Kellyhayes M, Beiser A, Kase CS, Benjamin EJ, D'Agostino RB: Stroke Severity in Atrial Fibrillation The Framingham Study. Stroke 1996;27:1760-1764.

31. Steffel J, Verhamme P, Potpara TS, Albaladejo P, Antz M, Desteghe L, Haeusler KG, Oldgren J, Reinecke H, Roldan-Schilling V, Rowell N, Sinnaeve P, Collins R, Camm AJ, Heidbuchel H; ESC Scientific Document Group: The 2018 European Heart Rhythm Association Practical Guide on the use of non-Vitamin K antagonist oral anticoagulants in patients with atrial fibrillation. Eur Heart J 2018;39:1330-1393.

32. Lenihan CR, Montezrath ME, Shen JI, Scandling JD, Turakhia MP, Chang TI, Winkelmayer WC: Correlates and outcomes of warfarin initiation in kidney transplant recipients newly diagnosed with atrial fibrillation. Nephrol Dial Transpl 2015;30:321-329.

33. Ruff CT, Giugliano RP, Braunwald E, Hoffman EB, Deenadayalu N, Ezekowitz MD, Camm AJ, Weitz JI, Lewis BS, Parkhomenko A, Yamashita T, Antman EM: Comparison of the efficacy and safety of new oral anticoagulants with warfarin in patients with atrial fibrillation: a meta-analysis of randomised trials. Lancet 2014;383:955-962.

34. Vanhove T, Spriet I, Annaert P, Maertens J, Van Cleemput J, Vos R, Kuypers D: Effect of the Direct Oral Anticoagulants Rivaroxaban and Apixaban on the Disposition of Calcineurin Inhibitors in Transplant Recipients. Ther Drug Monit 2017;39:77-82.

35. Wannhoff A, Weiss KH, Schemmer P, Stremmel W, Gotthardt D: Increased levels of rivaroxaban in patients after liver transplantation treated with cyclosporine A. Transplantation 2014;98:12-13

Table1. Baseline characteristics of the study population

\begin{tabular}{|c|c|c|c|c|c|}
\hline Characteristics & $\begin{array}{l}\text { Renal transplant } \\
\text { recipients }(\mathrm{n}=9)\end{array}$ & $\begin{array}{l}\text { Hepatic } \\
\text { transplant } \\
\text { recipients }(\mathrm{n}=5)\end{array}$ & $\begin{array}{l}\text { Transplant } \\
\text { Group (All } \\
\text { recipients; } n=14 \text { ) }\end{array}$ & $\begin{array}{l}\text { Control Group } \\
(\mathrm{n}=56)\end{array}$ & P-value* \\
\hline Age, years & $57.9 \pm 3.7$ & $61.0 \pm 7.9$ & $59.0 \pm 5.5$ & $59.1 \pm 5.3$ & 0.797 \\
\hline Male, n (\%) & $7(77.8)$ & $4(80.0)$ & $11(78.6)$ & $44(78.6)$ & 1.000 \\
\hline BMI, $\mathrm{Kg} / \mathrm{m}^{2}$ & $26.8 \pm 5.0$ & $25.2 \pm 1.3$ & $26.2 \pm 4.1$ & $26.3 \pm 1.9$ & 0.702 \\
\hline $\begin{array}{l}\text { AF duration, } \\
\text { months }\end{array}$ & $44.9 \pm 38.9$ & $52.6 \pm 59.3$ & $47.6 \pm 45.1$ & $49.4 \pm 54.4$ & 0.819 \\
\hline $\begin{array}{l}\text { Type of AF, n } \\
(\%)\end{array}$ & & & & & 1.000 \\
\hline Persistent AF & $2(22.2)$ & $1(20.0)$ & $3(21.4)$ & $12(21.4)$ & \\
\hline $\begin{array}{l}\text { Paroxysmal } \\
\mathrm{AF}\end{array}$ & $7(77.8)$ & $4(80.0)$ & $11(78.6)$ & $44(78.6)$ & \\
\hline $\begin{array}{l}\text { Congestive } \\
\text { heart failure, n } \\
(\%)\end{array}$ & $1(11.1)$ & $0(0.0)$ & $1(7.1)$ & $3(5.4)$ & 1.000 \\
\hline
\end{tabular}




\begin{tabular}{|c|c|c|c|c|c|}
\hline Characteristics & $\begin{array}{l}\text { Renal transplant } \\
\text { recipients }(\mathrm{n}=9)\end{array}$ & $\begin{array}{l}\text { Hepatic } \\
\text { transplant } \\
\text { recipients }(\mathrm{n}=5)\end{array}$ & $\begin{array}{l}\text { Transplant } \\
\text { Group (All } \\
\text { recipients; } \mathrm{n}=14 \text { ) }\end{array}$ & $\begin{array}{l}\text { Control Group } \\
(\mathrm{n}=56)\end{array}$ & P-value* \\
\hline $\begin{array}{l}\text { Hypertension, } \\
\mathrm{n}(\%)\end{array}$ & $7(77.8)$ & $4(80.0)$ & $11(78.6)$ & $34(60.7)$ & 0.350 \\
\hline $\begin{array}{l}\text { Diabetes } \\
\text { mellitus, n (\%) }\end{array}$ & $2(22.2)$ & $1(20.0)$ & $3(21.4)$ & $15(26.8)$ & 1.000 \\
\hline $\begin{array}{l}\text { Stroke/TIA, n } \\
(\%)\end{array}$ & $1(11.1)$ & $1(20.0)$ & $2(14.3)$ & $4(7.1)$ & 0.592 \\
\hline $\begin{array}{l}\text { Coronary } \\
\text { heart disease, } \\
\text { n }(\%) \\
\text { Laboratory } \\
\text { characteristics }\end{array}$ & $4(44.4)$ & $0(0.0)$ & $4(28.6)$ & $6(10.7)$ & 0.104 \\
\hline $\begin{array}{l}\text { Hemoglobin, } \\
\text { g/L }\end{array}$ & $144.1 \pm 16.9$ & $157.0 \pm 23.5$ & $148.7 \pm 19.7$ & $151.3 \pm 14.5$ & 0.649 \\
\hline Platelet, $10^{9} / \mathrm{L}$ & $215.3 \pm 78.9$ & $169.2 \pm 47.4$ & $198.8 \pm 71.0$ & $209.7 \pm 49.0$ & 0.209 \\
\hline $\mathrm{ALT}, \mathrm{IU} / \mathrm{L}$ & $18.8 \pm 10.3$ & $24.6 \pm 10.5$ & $20.9 \pm 10.4$ & $22.8 \pm 10.8$ & 0.814 \\
\hline AST, IU/L & $21.3 \pm 5.2$ & $24.8 \pm 5.5$ & $22.6 \pm 5.4$ & $21.8 \pm 5.1$ & 0.417 \\
\hline $\begin{array}{l}\text { Total } \\
\text { bilirubin, } \\
\mu \mathrm{mol} / \mathrm{L}\end{array}$ & $16.6 \pm 3.3$ & $19.0 \pm 10.0$ & $17.5 \pm 6.2$ & $15.8 \pm 6.2$ & 0.325 \\
\hline $\begin{array}{l}\text { Direct } \\
\text { bilirubin, } \\
\mu \mathrm{mol} / \mathrm{L}\end{array}$ & $4.1 \pm 1.0$ & $3.6 \pm 1.4$ & $3.9 \pm 1.1$ & $3.4 \pm 1.3$ & 0.144 \\
\hline $\begin{array}{l}\text { Creatinine, } \\
\mu \mathrm{mol} / \mathrm{L}\end{array}$ & $89.4 \pm 27.7$ & $86.7 \pm 11.8$ & $88.4 \pm 22.8$ & $74.6 \pm 14.7$ & 0.017 \\
\hline $\begin{array}{l}\text { eGFR, } \\
\mathrm{ml} / \mathrm{min} / 1.73 \mathrm{~m}^{2} \\
\text { Echocardiographic } \\
\text { parameters }\end{array}$ & $80.4 \pm 15.6$ & $80.3 \pm 11.9$ & $80.3 \pm 13.9$ & $91.9 \pm 12.6$ & 0.007 \\
\hline $\mathrm{LAD}, \mathrm{mm}$ & $39.1 \pm 6.3$ & $40.4 \pm 4.6$ & $39.6 \pm 5.6$ & $39.5 \pm 3.1$ & 0.929 \\
\hline LVEDD, mm & $49.9 \pm 6.1$ & $45.2 \pm 3.0$ & $48.2 \pm 5.6$ & $48.7 \pm 3.7$ & 0.802 \\
\hline $\begin{array}{l}\text { LVEF, \% } \\
\text { EHRA } \\
\text { stratification, } \\
\text { n }(\%)\end{array}$ & $61.2 \pm 6.8$ & $62.4 \pm 2.8$ & $61.6 \pm 5.6$ & $63.4 \pm 4.1$ & $\begin{array}{l}0.430 \\
0.812\end{array}$ \\
\hline EHRA II & $1(11.1)$ & $1(20.0)$ & $2(14.3)$ & $10(17.9)$ & \\
\hline EHRA III & $7(77.8)$ & $4(80.0)$ & $11(78.6)$ & $44(78.6)$ & \\
\hline EHRA IV & $1(11.1)$ & $0(0.0)$ & $1(7.1)$ & $2(3.6)$ & \\
\hline $\begin{array}{l}\mathrm{CHA}_{2} \mathrm{DS}_{2-} \\
\text { VAS }_{\mathrm{C}} \\
\text { score }\end{array}$ & $2.1 \pm 0.8$ & $2.0 \pm 1.2$ & $2.1 \pm 0.9$ & $1.2 \pm 1.1$ & 0.002 \\
\hline $\begin{array}{l}\text { HAS-BLED } \\
\text { score } \\
\text { OAC }\end{array}$ & $1.9 \pm 0.3$ & $2.4 \pm 0.9$ & $2.1 \pm 0.6$ & $0.9 \pm 0.7$ & ¡0.001 \\
\hline $\begin{array}{l}\text { Warfarin, } \mathrm{n} \\
(\%)\end{array}$ & $4(44.4)$ & $1(20.0)$ & $5(35.7)$ & $9(16.1)$ & 0.135 \\
\hline NOAC, n (\%) & $5(55.6)$ & $4(80.0)$ & $9(64.3)$ & $47(83.9)$ & 0.135 \\
\hline
\end{tabular}


Values are given as number (percent) or mean $\pm \mathrm{SD}$. ${ }^{*} \mathrm{P}$-value, transplant group vs. control group.

$\mathrm{AF}=$ atrial fibrillation; $\mathrm{BMI}=$ body mass index $\mathrm{ALT}=$ alanine aminotransferase $; \mathrm{AST}=$ aspartate aminotransferase; $\mathrm{TIA}=$ transient ischemic attack; $\mathrm{eGFR}=$ estimated glomerular filtration rate; LAD=left atrium diameter; $L V E D D=$ left ventricular end diastolic diameter; $L V E F=$ left ventricular ejection fraction; $\mathrm{EHRA}=$ European Heart Rhythm Association; $\mathrm{OAC}=$ oral anticoagulant $; \mathrm{NOAC}=$ non-vitamin $\mathrm{K}$ antagonist oral anticoagulant.

Table 2. Clinical features of 14 patients with liver or kidney transplantation

\begin{tabular}{|c|c|c|c|c|c|c|c|c|c|}
\hline No & Gender & Age & AF-type & $\begin{array}{l}\text { AF } \\
\text { duration } \\
\text { (months) }\end{array}$ & $\begin{array}{l}\text { History } \\
\text { of trans- } \\
\text { planta- } \\
\text { tion } \\
\text { (years) }\end{array}$ & $\begin{array}{l}\mathrm{AST} \\
\mathrm{IU} / \mathrm{L}\end{array}$ & $\begin{array}{l}\text { ALT } \\
\mathrm{IU} / \mathrm{L}\end{array}$ & $\begin{array}{l}\text { Scr } \\
\mu \mathrm{mol} / \mathrm{L}\end{array}$ & $\begin{array}{l}\text { Anti- } \\
\text { rejection } \\
\text { drugs }\end{array}$ \\
\hline $\begin{array}{l}\text { Patients } \\
\text { with }\end{array}$ & $\begin{array}{l}\text { Patients } \\
\text { with }\end{array}$ & $\begin{array}{l}\text { Patients } \\
\text { with }\end{array}$ & $\begin{array}{l}\text { Patients } \\
\text { with }\end{array}$ & $\begin{array}{l}\text { Patients } \\
\text { with }\end{array}$ & $\begin{array}{l}\text { Patients } \\
\text { with }\end{array}$ & $\begin{array}{l}\text { Patients } \\
\text { with }\end{array}$ & $\begin{array}{l}\text { Patients } \\
\text { with }\end{array}$ & $\begin{array}{l}\text { Patients } \\
\text { with }\end{array}$ & $\begin{array}{l}\text { Patients } \\
\text { with }\end{array}$ \\
\hline liver & liver & liver & liver & liver & liver & liver & liver & liver & liver \\
\hline $\begin{array}{l}\text { trans- } \\
\text { planta- }\end{array}$ & $\begin{array}{l}\text { trans- } \\
\text { planta- }\end{array}$ & $\begin{array}{l}\text { trans- } \\
\text { planta- }\end{array}$ & $\begin{array}{l}\text { trans- } \\
\text { planta- }\end{array}$ & $\begin{array}{l}\text { trans- } \\
\text { planta- }\end{array}$ & $\begin{array}{l}\text { trans- } \\
\text { planta- }\end{array}$ & $\begin{array}{l}\text { trans- } \\
\text { planta- }\end{array}$ & $\begin{array}{l}\text { trans- } \\
\text { planta- }\end{array}$ & $\begin{array}{l}\text { trans- } \\
\text { planta- }\end{array}$ & $\begin{array}{l}\text { trans- } \\
\text { planta- }\end{array}$ \\
\hline & tion & tion & tion & tion & tion & tion & tion & tion & tion \\
\hline$(1-5)$ & $(1-5)$ & $(1-5)$ & $(1-5)$ & $(1-5)$ & $(1-5)$ & $(1-5)$ & $(1-5)$ & $(1-5)$ & $(1-5)$ \\
\hline 1 & Male & 62 & PeAF & 24 & 10 & 34 & 30 & - & $\mathrm{TAC}+\mathrm{MM}$ \\
\hline 2 & Male & 48 & PAF & 24 & 10 & 24 & 40 & - & $\mathrm{CsA}+\mathrm{MMF}$ \\
\hline 3 & Male & 69 & PAF & 11 & 13 & 21 & 20 & - & $\mathrm{TAC}+\mathrm{MMF}$ \\
\hline 4 & Female & 65 & PAF & 48 & 9 & 20 & 13 & - & $\mathrm{CS}+\mathrm{TAC}$ \\
\hline 5 & Male & 61 & PAF & 156 & 10 & 25 & 20 & - & TAC \\
\hline $\begin{array}{l}\text { Patients } \\
\text { with }\end{array}$ & $\begin{array}{l}\text { Patients } \\
\text { with }\end{array}$ & $\begin{array}{l}\text { Patients } \\
\text { with }\end{array}$ & $\begin{array}{l}\text { Patients } \\
\text { with }\end{array}$ & $\begin{array}{l}\text { Patients } \\
\text { with }\end{array}$ & $\begin{array}{l}\text { Patients } \\
\text { with }\end{array}$ & $\begin{array}{l}\text { Patients } \\
\text { with }\end{array}$ & $\begin{array}{l}\text { Patients } \\
\text { with }\end{array}$ & $\begin{array}{l}\text { Patients } \\
\text { with }\end{array}$ & $\begin{array}{l}\text { Patients } \\
\text { with }\end{array}$ \\
\hline kidney & kidney & kidney & kidney & kidney & kidney & kidney & kidney & kidney & kidney \\
\hline trans- & trans- & trans- & trans- & trans- & trans- & trans- & trans- & trans- & trans- \\
\hline & & & & & & & & $\begin{array}{l}\text { planta- } \\
\text { tion }\end{array}$ & $\begin{array}{l}\text { planta- } \\
\text { tion }\end{array}$ \\
\hline$(6-14)$ & $(6-14)$ & $(6-14)$ & $(6-14)$ & $(6-14)$ & $(6-14)$ & $(6-14)$ & $(6-14)$ & $(6-14)$ & $(6-14)$ \\
\hline 6 & Male & 63 & $\mathrm{PeAF}$ & 84 & 5 & - & - & 90.4 & $\mathrm{TAC}+\mathrm{MMF}$ \\
\hline 7 & Male & 57 & $\mathrm{PeAF}$ & 120 & 11 & - & - & 88.8 & $\mathrm{CS}+\mathrm{SRL}+\mathrm{N}$ \\
\hline 8 & Male & 58 & PAF & 60 & 4 & - & - & 81.3 & $\mathrm{CS}+\mathrm{TAC}+1$ \\
\hline 9 & Male & 50 & PAF & 24 & 20 & - & - & 160.5 & $\mathrm{TAC}+\mathrm{MM}$ \\
\hline 10 & Male & 56 & PAF & 24 & 7 & - & - & 78.8 & $\mathrm{CS}+\mathrm{TAC}+$ \\
\hline 11 & Male & 59 & PAF & 2 & 9 & - & - & 86.8 & $\mathrm{CS}+\mathrm{CsA}+$ \\
\hline 12 & Female & 62 & PAF & 12 & 23 & - & - & 69.3 & $\mathrm{CS}+\mathrm{CsA}+$ \\
\hline 13 & Female & 58 & PAF & 60 & 4 & - & - & 70.1 & $\mathrm{CS}+\mathrm{CsA}+$ \\
\hline 14 & Male & 58 & PAF & 18 & 9 & - & - & 78.5 & $\mathrm{CS}+\mathrm{TAC}-$ \\
\hline
\end{tabular}

$\mathrm{PAF}=$ Paroxysmal atrial fibriallaion; $\mathrm{PeAF}=\mathrm{Persistent}$ atrial fibrillation; $\mathrm{AF}=$ atrial fibrillation; Scr=Serum creatine; AST=aspartate aminotransferase; ALT=alanine aminotransferase; TAC=tacrolimus; $\mathrm{MMF}=$ Mycophenolate $\quad$ mofetil; $\quad \mathrm{CsA}=$ cyclosporine $\quad \mathrm{A} ; \quad \mathrm{CS}=$ corticosteroids; $\quad$ Aza=Azathioprine; $\mathrm{SRL}=$ Sirolimus. Table3. Procedural characteristics and periprocedural complications

\begin{tabular}{llll}
\hline & Transplant Group & Control Group & P-value \\
\hline Number of patients, $(\mathrm{n})$ & 14 & 56 & -
\end{tabular}




\begin{tabular}{|c|c|c|c|}
\hline & Transplant Group & Control Group & $\mathrm{P}$-value \\
\hline $\begin{array}{l}\text { Number of procedures, } \\
\text { (n) }\end{array}$ & 15 & 62 & - \\
\hline Repeat ablation, n (\%) & $1(7.1)$ & $6(10.7)$ & 1.000 \\
\hline $\begin{array}{l}\text { Procedure time, } \\
\text { minutes }\end{array}$ & $135.7 \pm 41.3$ & $129.8 \pm 41.1$ & 0.529 \\
\hline $\begin{array}{l}\text { Fluoroscopic time, } \\
\text { minutes }\end{array}$ & $7.9 \pm 5.7$ & $6.3 \pm 4.8$ & 0.568 \\
\hline \multicolumn{4}{|l|}{ Procedure strategy } \\
\hline CPVI, n (\%) & $15(100.0)$ & $61(98.4)$ & 0.621 \\
\hline CTI, n (\%) & $9(60.0)$ & $25(40.3)$ & 0.168 \\
\hline $\begin{array}{l}\text { Other linear ablation, } \\
\mathrm{n}(\%)\end{array}$ & $6(40.0)$ & $19(30.6)$ & 0.545 \\
\hline SVCI, n (\%) & $1(6.7)$ & $6(9.7)$ & 1.000 \\
\hline Cardioversion, n (\%) & $5(33.3)$ & $17(27.4)$ & 0.752 \\
\hline \multicolumn{4}{|l|}{$\begin{array}{l}\text { Periprocedural } \\
\text { complications }\end{array}$} \\
\hline Stroke/TIA, n (\%) & $0(0.0)$ & $0(0.0)$ & - \\
\hline $\begin{array}{l}\text { Cardiac } \\
\text { tamponade/effusion, } \mathrm{n} \\
(\%)\end{array}$ & $0(0.0)$ & $0(0.0)$ & - \\
\hline $\begin{array}{l}\text { Myocardial infarction, } \\
\mathrm{n}(\%)\end{array}$ & $0(0.0)$ & $0(0.0)$ & - \\
\hline Major bleeding, n (\%) & $0(0.0)$ & $0(0.0)$ & - \\
\hline $\begin{array}{l}\text { Pseudoaneurysm, n } \\
(\%)\end{array}$ & $0(0.0)$ & $1(1.6)$ & 1.000 \\
\hline $\begin{array}{l}\text { Groin hematoma, } \mathrm{n} \\
(\%)\end{array}$ & $1(6.7)$ & $1(1.6)$ & 0.354 \\
\hline
\end{tabular}

Values are given as number (percent) or mean $\pm \mathrm{SD}$. CPVI=circumferential pulmonary vein isolation; $\mathrm{CTI}=$ cavo-tricuspid isthmus; $\mathrm{SVCI}=$ superior vena cava isolation; TIA $=$ transient ischemic attack.

Figure legends 

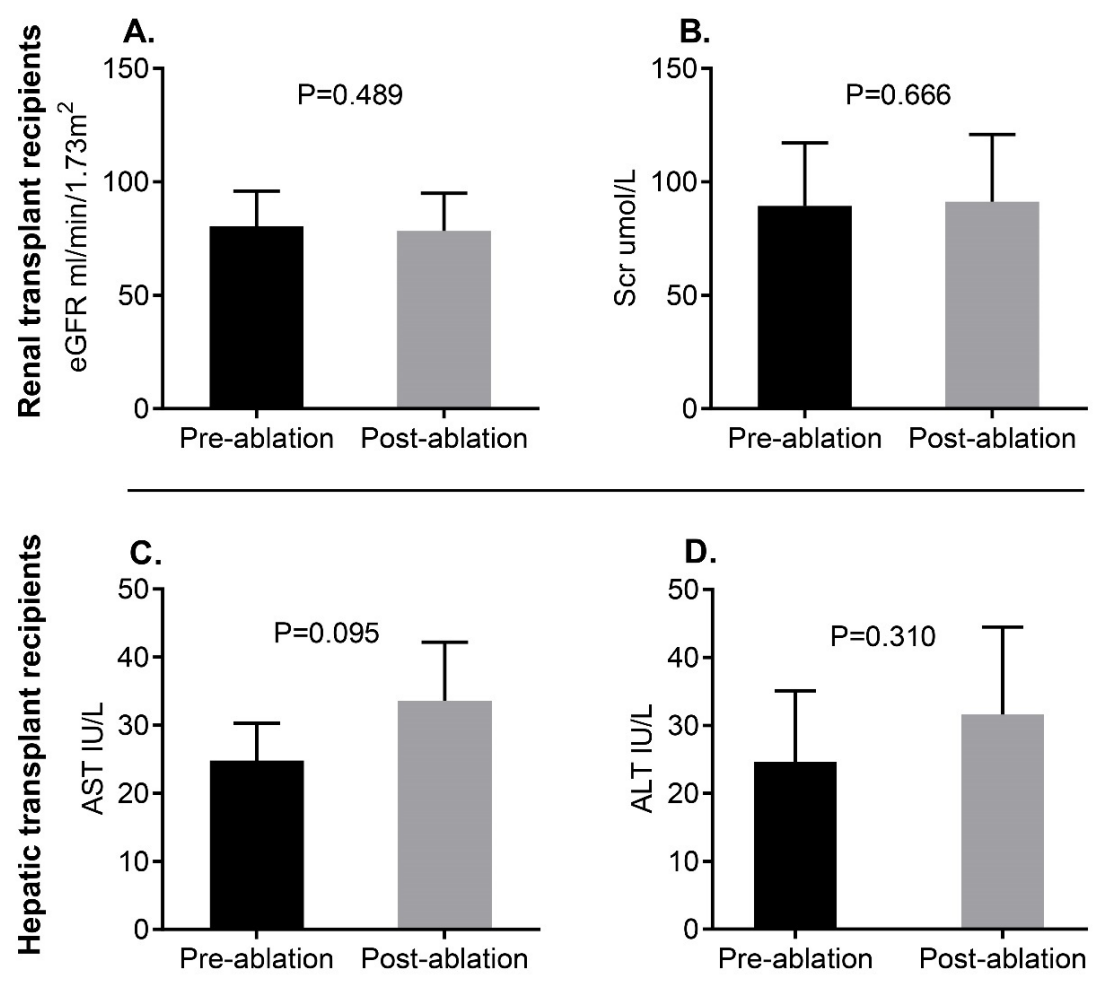

Figure 1 The effect of catheter ablation on the function of transplanted organ during perioperative period

The effect of catheter ablation on the serum creatinine (Scr) and estimated glomerular filtration rate (eGFR) in kidney transplantation recipients during perioperative period (A-B); the effect of catheter ablation on the alanine aminotransaminase (ALT) and aspartate aminotransferase (AST) in hepatic transplant recipients $(\mathrm{C}-\mathrm{D})$ 
A.

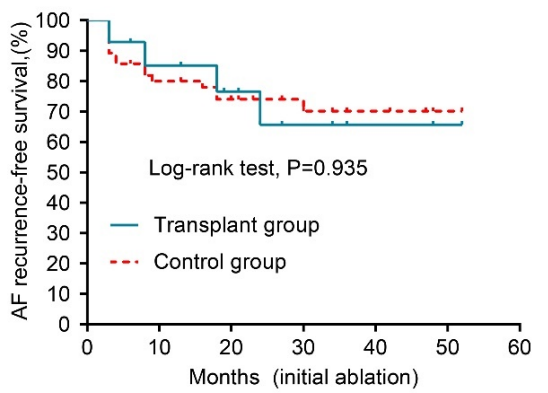

C.

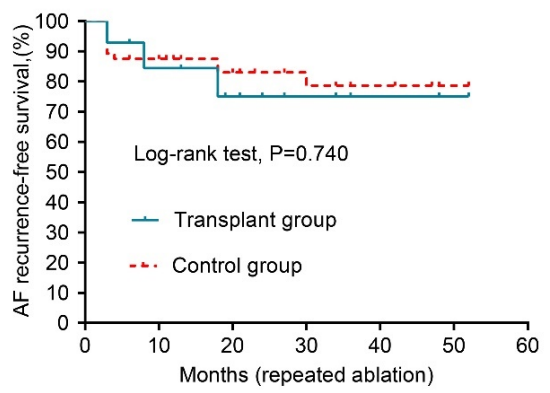

B.

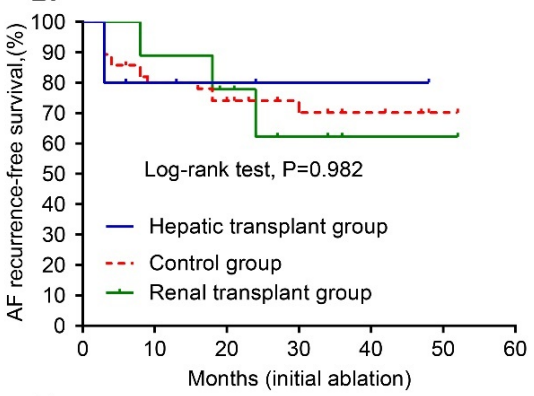

D.

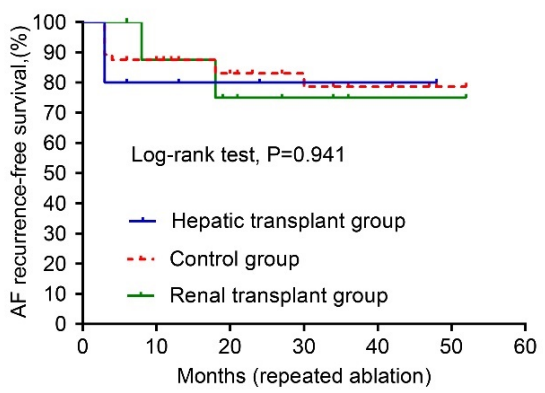

Figure 2 Kaplan-Meier analysis of the time to recurrent AF after the catheter ablation procedure among groups

Time to recurrent $\mathrm{AF}$ after the initial catheter ablation procedure (A-B), and repeated catheter ablation procedure $(\mathrm{C}-\mathrm{D})$ among groups. $\mathrm{AF}=$ atrial fibrillation. 